\title{
INFORMATION TECHNOLOGY, INTERNET, AND MARKETING
}

\author{
Mihane Berisha-Namani \\ University of Pristina
}

Str. Agim Ramadani, No Number, 10000 Pristina, Republic of Kosova Mihane_Berisha@yahoo.com

\begin{abstract}
Information technology developed very fast, and today's marketing activities are not possible without the help of information technology. Furthermore, it is difficult to think of a policy domain not affected by usage of information technology. Information technology is making possible and creating connections between businesses and organizations. The implications of information technology usage in marketing activities are profound too. Using information technology, companies possess the potential to reach more customers, introduce new products and services quickly, and collaborate with suppliers and business partners from all over the world. We should emphasize that information technology usage in marketing supports an integral approach to all marketing activities of a company and produces a large amount of information on buyers and markets. The aim of this paper is to describe information technology usage for marketing purposes. This paper starts with a description of information technology usage in business. It transitions into highlighting information technology and its role in marketing. The last part draws out the main conclusions and suggests that more attention should be paid to the potential of information technology usage for marketing purposes since this technology today is the key to better marketing activities and success in business.
\end{abstract}

Keywords: Information Technology, Internet, Marketing Activities, Electronic Marketing.

\section{INTRODUCTION}

Dynamics of the development of information technology and its fast usage brought major changes in modern business development and marketing activities. In the last decade research showed an increase of the impact of information technology in organization structures of enterprises 
and their business activities. In the field of marketing, information technology is used to realize significant marketing functions such as information on markets and business in general, marketing research, product development, and service and distribution.

As a result of information technology usage, enterprise business systems are characterized by major changes in their marketing systems, with standard products, low prices due to the impact of competition, short distribution channels, non-linear promotion, electronic funds transfer, management information systems and databases, as well as improvement of relationships with business partners and customers enabling them to create closer relations with their buyers in global markets.

In this paper, the use of information technology in marketing starts with an introduction and a brief description of the use of this technology in business and continues with a special emphasis of usage of information technology in marketing activities. Finally, although the scientific literature, began to put out the role and importance of information technology in business processes in the organization and empirical researche, shows an exponential growth of the needs of organizations for information and information technology usage, they have not yet understood the importance of information technology for business and marketing purposes and do not pay enough attention. Therefore, more research is required in this regard.

\section{INFORMATION TECHNOLOGY AND ITS ROLE IN BUSINESS}

With the introduction of the science of cybernetics in 1948 in Paris, later informatics and computer sciences ${ }^{1}$ began to develop the role and importance of information technology in business processes. However, only in the era of information society and knowledge economy does information becomes an important economic resource and information technology an integral part of business processes ${ }^{1}$. Today, information is the most-precious commodity in the market, becoming the new raw material, resource of the future, power, money, and key factor of productivity growth and business success.

We live in a time when we can easily gather a large amount of information. Before, the main problem was how to appropriately, quickly, and easily provide the necessary information. Today, the main problem is the availability of a great amount of information. Through electronic and communication media circulate millions of pieces of information. Moreover, in the contemporary conditions of development, information is an important resource in the enterprises. In order to gather the necessary data on the market about customers, their needs, habits, and process data to information, 
companies use computers, information technology, and information systems. Therefore, the role of information technology in marketing can be compared with the role of blood in human body.

Furthermore, according to Haag, Baltzan, and Philips ${ }^{2}$, business activities and marketing activities cannot be realized without the use of information technology, marketing managers cannot make quality decisions, marketing strategies cannot be designed, and business policies cannot be oriented. Therefore, in modern enterprises all important managerial positions must be connected to computer networks and use information technology $y^{\mathrm{a}}$.

We should note that the role and importance of information technology in marketing increase, with the increasing complexity of business ${ }^{1}$. Moreover, as never before, enterprises today are in the situation of developing their activities in a competitive business environment, characterized by high competition and quick decisions. In these situation, they must possess marketing information ${ }^{b}$ to reduce risk and uncertainty in decision making and increase the probability of making right decisions ${ }^{1}$. To achieve this, it is necessary to collect data, evaluate them, and process information. In the absence of the use of information technology, these goals would be impossible to achieve, especially, if we consider that contemporary business and marketing activities are based on processes, tasks, and products, not functions.

In terms of marketing, the availability of information is needed because information is an economic resource for companies to achieve strategic advantages compared to their competition. For marketing purposes, this can provide information technology, which supports the marketing function and can facilitate the movement of goods and services from producers to customers ${ }^{3}$.

Furthermore, according to Milicevic ${ }^{4}$, the most-important factors of competitiveness in knowledge economy are innovations, quality of products and services, time, and lower costs. Usage of information technology to develop marketing activities generates information needed to provide knowledge about consumer behaviour, quickly an in a timely manner,

\footnotetext{
a Information technology is a set of tools which people use in order to work with information and support needs of organizations for the processing of information. For more, see: Haag, S. Baltzan, and P. Phillips, A.: Business Driven Technology, Mc GRAW-Hill, New York, 2006.

b Marketing information is processed marketing data that deal with certain aspects of a marketing system or its surroundings and are in a function of reduction of uncertainty in the process of marketing decisions. For more, see: H. Hanić: Marketing informacijski sistemi za menadžere, Beograd, 1998.
} 
enabling the reduction of uncertainty for marketing decision makers. This knowledge helps plan assortments, price setting, promotion of products and services, selecting sales channels, etc. ${ }^{5}$.

A replaceable source of marketing information is the Internet ${ }^{\mathrm{c}}$, which enables the creation of close relationships among business partners involved in selling and purchasing transactions for all market segments, ranging from enterprises to buyers and potential customers ${ }^{6}$. The Internet is used as a place to promote products and services and provide information about potential buyers and their power. Recently, some authors rightly pointed out that information technology is not only processing of information offering the look of data of a real system, but also a medium that offers techniques used in the field of artificial intelligence 6 . In fact, these are modern marketing systems in the function of the process of marketing decision making.

Milicević ${ }^{4}$, pointed out that in modern conditions of business development, competition between enterprises or classic companies and Internet companies is not in technology but in the way of better fulfilling of the needs and wishes of consumers. Information technology is the factor of success and efficiency in business. Furthermore, to be competitive, companies are forced to increase their competitive abilities and their presence in the global market. That a consumer will purchase a physical book in a bookstore, or will order it from a digital company does not depend upon which company has the best Web-site or who is faster on the Internet, but depends on which better understands customer's needs and makes the best offer in comparison to competition ${ }^{7}$.

\section{INFORMATION TECHNOLOGY AND ITS ROLE IN MARKETING}

No doubt, the 1980s and orientation towards the enterprise market were golden years in the area of marketing, because they saw the largest achievements of marketing compared with the orientation of enterprises in manufacturing and sales. Today, marketing is much more than a business function and is coordinated with other business functions in company

\footnotetext{
c A global computer network and the network of computer networks: The Internet was created in 1969, known as the ARPANET project of the Ministry of Defense of the United States of America and aimed to link military and research centers. Over the time, the ARPANET network began to link the computer networks of universities and scientific centers, including networks Usenet and NSFnet, so that in the 1990s, this network expanded outside academia and for commercial service with the introduction of the WWW (World Wide Web). The Internet became a global phenomenon and the largest medium.
} 
activities. Peter Drucker, cited by Hanić ${ }^{1}$, pointed out that "marketing is an essential function of business and cannot be seen as an independent function". The role of marketing is interactive a bridge between the enterprise opportunities and customer's needs, the economy, and society in general for products and services. Therefore, one of the conditions that must be met for products and business enterprises to be known is the knowledge of marketing development through networks.

Usage of information technology in marketing enabling rapid and efficient communication, transfers of a large amount of information over distances, integration of multimedia documents, digitalization of shipment of goods and services, direct payments via the Internet, creation of virtual organizations, etc. All of these are elements of a new form of business, the so-called "electronic business" (e-business) ${ }^{\mathrm{d}}$. If traditionally, classic marketing is defined as adaptation of actions and company activities surrounding market conditions in order to better meet customers' needs and requirements, the question becomes "What is electronic marketing?"

In contemporary marketing literature, marketing is defined by Kotler ${ }^{8}$, as "the social and managerial process through which individuals and groups benefit from what they need and what they want through the creation, delivery, and exchange of products available to others". This definition also serves as the basis upon definition of electronic marketing.

In fact, "electronic marketing" is a general term we started to hear in the last decade. It includes all marketing activities online and enables producers and sellers to contact customers quickly and easily in order to meet their needs, wishes, and requirements ${ }^{9}$. Some authors (Mohammed, Fisher, Jaworski, and Paddison) define "electronic marketing" as a process of creating and maintaining online relationships with customers and fulfilment of their needs ${ }^{10}$.

Furthermore, electronic marketing is a form of electronic business that uses information technology and electronic media to carry out marketing activities in an organization ${ }^{11}$. Electronic marketing focuses more on online communication and usage of direct dialogue with customers in order to increase their loyalty for the products of the organization. Electronic marketing finds its applications in the Internet and mobile technology and can be supplemental to traditional marketing or represent a completely new form of contemporary business. Therefore, we often hear some terms such as "Internet marketing", "digital marketing", "online marketing", "virtual

\footnotetext{
${ }^{\mathrm{d}}$ Electronic business is a general concept of business that includes all forms of business transactions which are realized with the help of information and communication technology (ICT technology).
} 
marketing", "cyber marketing", and "Web marketing". It should be pointed out that electronic marketing is usually used with other media and in coordination with online and offline activities.

Table 1. Differences between classic marketing and electronic marketing

\begin{tabular}{|c|c|}
\hline Classic marketing & Electronic marketing \\
\hline Local and regional market & Global market \\
\hline Limited time availability & Availability $24 \mathrm{~h} /$ week \\
\hline Mass marketing & $\begin{array}{l}\text { Marketing one-to-one (towards a } \\
\text { user) }\end{array}$ \\
\hline No interaction & $\begin{array}{l}\text { Interaction and communication in } \\
\text { two directions }\end{array}$ \\
\hline Large financial investments & Large financial efficiency \\
\hline Diffuse emissions & Emissions across the Internet \\
\hline Heterogeneous set of users & Homogeneous set of users \\
\hline $\begin{array}{l}\text { Difficulties in the evaluation of } \\
\text { marketing activities }\end{array}$ & $\begin{array}{l}\text { Measurement of results of } \\
\text { marketing activities }\end{array}$ \\
\hline
\end{tabular}

Electronic marketing means not only creating a Web-site, but focusing more on communication online, using direct dialogue with customers in order to enable them to carry out business activities easier. Electronic marketing includes several activities such as communication with customers, their loyalty, and positioning of products or services on computer networks. Therefore, electronic marketing entails everything that organizations do online to find and maintain customers ${ }^{12}$.

Internet companies must follow traditional marketing concepts so that users find the same content regardless of which media they use, creating relationships with customers. While the traditional marketing expenses for realization of marketing activities are high, in electronic marketing everyone who owns an Internet connection is a potential customer or suppliers to one another and the costs are very low.

\section{CONCLUSION}

Application of information technology in marketing as well as in all other forms of business changed the classical way of marketing activities, and brought major changes in the marketing system. Electronic marketing is a characteristic of contemporary business, and marketing activities are rapidly transformed as a result of using of information technology. Information technology usage to support marketing activities is imperative. Enterprises that do not know what is happening in their business 
environment or utilize electronic marketing can be successful in the short term, but never gain strategic benefits from information technology and its use.

The speed and success of the application of information technology in marketing are key factors to business success. The global scale proved that the use of information technology in marketing is a necessity. Noting that usage of information technology in business continuously generates new business models, new types of partnerships and new ways of success, we believe that enterprises should benefit from the usage of information technology in marketing and its unique potential of interactivity with electronic marketing.

\section{REFERENCES}

[1] H. Hanić, Marketing informacijski sistemi - za menadžere (6 ${ }^{\text {th }}$ ed.). Beograd: Čigoja Štampa, 1998.

[2] S. Haag, P. Baltzan, and A. Phillips, Business driven technology. New York : McGraw-Hill, 2006.

[3] L. Terry, Management Information Systems ( $9^{\text {th }}$ ed.). London: Thomson Learning, 2005.

[4] V. Milicević, Internet ekonomija. Beograd: Fakultet Oragnizacionih Nauka, 2002.

[5] B. Markić, S. Kukić, and D. Tomić, Marketing information system for discovering consumer preferences in the purchase decision making process. Retrieved on June 28, 2010, from http://www.google.com/search?h1=en\&q=marketing+informacijski+su stav\&start $=70 \& s a=N$.

[6] D. Steinbock, The birth of internet marketing communications. Westport: Quorum Books, 2001.

[7] M. Berisha-Namani, Biznesi elektronik ( $1^{\text {st }}$ ed.). Prishtinë: University of Pristina, 2012.

[8] Ph. Kotler, Marketing management, The Millennium Edition (10 ${ }^{\text {th }}$ ed.). Boston: Pearson Custom Publishing, 2002.

[9] N. Vidić, Primena Internet marketinga na razvoj Web portala. Beograd: Fakultet Organizacionih Nauka.

[10] R. Mohammed, R.J. Fisher, B.J. Jaworski, and G. Paddison, Internet Marketing - Building Advantage in a Networked Economy ( $2^{\text {nd }}$ ed.). New York: McGraw-Hill College, 2001. Retrieved on June 24, 2008 from http://analogik.com/article_priciples_of_emarketing.asap.

[11] Ph. Kotler, Upravljanje marketingom. Zagreb: Informator, 1998.

[12] Retrieved on January 23, 2010, from http://en.wikipedia.org/w/index.php?title=Template:Marketing\&action =edit. 
